\begin{tabular}{|c|}
\hline 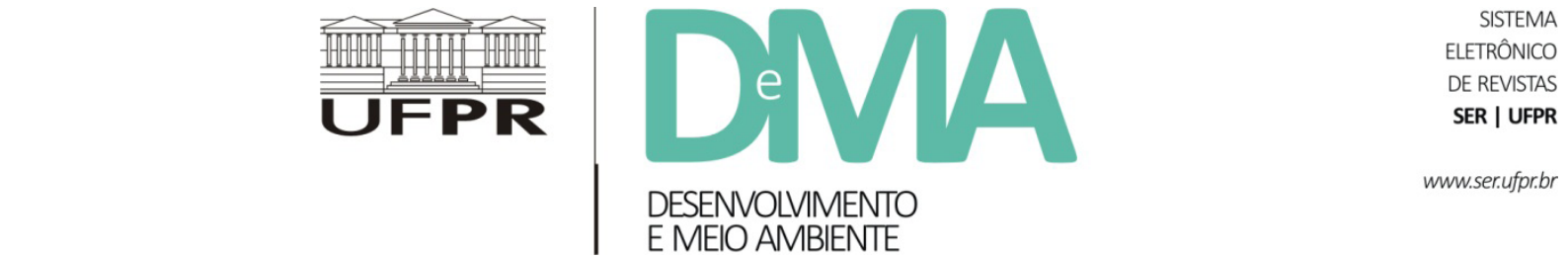 \\
\hline
\end{tabular}

\title{
Desvelando discursos: insustentabilidade e poder nos agrocombustíveis
}

\section{Unveiling Discourses: Unsustainability and Power of Agro Fuels}

\author{
Marina de Oliveira PENIDO ${ }^{*}$ \\ ${ }^{1}$ Universidade Federal Fluminense (UFF), Niterói, RJ, Brasil. \\ *E-mail de contato: marinaopenido@yahoo.com.br
}

Artigo recebido em 28 de agosto de 2015, versão final aceita em 7 de junho de 2016.

RESUMO: O artigo evidencia os interesses econômicos embutidos no discurso socioambiental dos agrocombustíveis, retratando as alianças empresariais firmadas entre grandes transnacionais do agronegócio, da biotecnologia e dos segmentos petroleiro e automobilístico. Questionando a insustentabilidade dos agrocombustíveis, discutimos sobre os fins que norteiam sua produção: os veículos automotores. Ao tecermos considerações sobre a trama geopolítica dos agrocombustíveis, recorremos às noções de "acumulação por espoliação" e "novo imperialismo", apontando para a inserção dos países latino-americanos, caribenhos e africanos na divisão internacional do trabalho como fornecedores de matérias-primas e energia para os países ditos desenvolvidos. Para tratar do discurso social dos agrocombustíveis destacamos, em função de seu caráter emblemático, o Programa Nacional de Produção e Uso de Biodiesel - PNPB. O PNPB é um programa de produção em larga escala de biodiesel, que procura se justificar e se legitimar pela incorporação da agricultura familiar à sua cadeia produtiva, como forma de geração de renda no campo. Nesse quadro, embora o programa ressalte a participação da agricultura familiar, observa-se, no seu perfil produtivo em escala nacional, a predominância do agribusiness. Este artigo procura descontruir o discurso socioambiental hegemônico dos agrocombustíveis lançando mão da literatura pertinente, da legislação existente para o biodiesel e de dados secundários, com ênfase naqueles difundidos pela Agência Nacional do Petróleo, Gás Natural e Biocombustíveis - ANP.

Palavras-chave: agrocombustíveis; discurso socioambiental; Programa Nacional de Produção e Uso de Biodiesel - PNPB.

ABSTRACT: This paper highlights the economic interests embedded the socio-environmental discourse on agro fuels, showing corporate alliances between major multinational agribusiness companies, biotechnology and the petroleum and automotive sector. Questioning the unsustainability of biofuels, the purposes guiding its production were discussed: automotive vehicles. When considerations were raised about the geopolitical plot of agro fuels, the concepts of "accumulation by dispossession" and "new imperialism" were mentioned, pointing to an insertion of Latin American, African and Caribbean countries into the international division of labor as raw material and energy suppliers to the so-called developed countries. To approach the agro fuels social discourse, due to 
its emblematic character, the National Program for Production and Use of Biodiesel - PNPB was highlighted. PNPB is a large scale program aiming biodiesel production, which seeks to justify and legitimize itself by the addition of family farming to the production chain as a way of generating income in the countryside. Although the program highlights the family farming participation, it is observed in its production profiles, at national level, the prevalence of agribusiness. This paper tries to break down the hegemonic socio-environmental discourse of agro fuels using the relevant bibliography, current legislation on biodiesel, and secondary data, with emphasis on those disseminated by National Agency of Petroleum, Natural Gas and Biofuels - ANP.

Keywords: agro fuels; socio-environmental discourse; National Program for Production and Use of Biodiesel $-\mathrm{PNPB}$.

\section{Introdução}

As mudanças climáticas e a necessidade de adequações às exigências do Protocolo de Quioto, para redução das emissões de gases de efeito estufa, têm justificado a ampliação das áreas destinadas às culturas agroenergéticas, sob o alicerce produtivo da adoção, nos mercados nacional e internacional, dos veículos flex-fuel (Assis \& Zuccarelli, 2007). Sob esse viés, o Estado atribui, cada vez mais, ao mercado a capacidade de resolver os problemas ambientais, resultando na redução do meio ambiente a uma "oportunidade de negócios" (Layrargues, 1998; Acselrad, 2001).

Diante das pressões internacionais pela busca de alternativas energéticas, políticas específicas de estímulo à substituição de combustíveis fósseis por agrocombustíveis estão sendo instituídas, tanto pelos Estados Unidos (a exemplo da Energy Independence and Security Act de 2007, que, por meio do Renewable Fuel Standard - RFS, propõe metas progressivas de produção e consumo de agrocombustíveis), quanto pela União Europeia (a exemplo da Directiva 2009/28/CE do Parlamento Europeu e do Conselho de 23 de abril de 2009, que propõe que as energias renováveis, como os agrocombustíveis, representem $10 \%$ do combustível consumido até 2020 no setor de transportes europeu) (Paixão \& Fonseca, 2008, Glenister \& Nunes, 2011; Penido, 2011).

No Brasil, a produção e o uso de agrocombustíveis também são estimulados por programas governamentais, como o Plano Nacional de Agroenergia - PNA - e o Programa Nacional de Produção e Uso do Biodiesel - PNPB. Conforme o discurso governamental, os agrocombustíveis são capazes de garantir desenvolvimento sustentável, diversificação da matriz energética e redução das importações de petróleo (Brasil, 2004).

Nesse cenário, a novidade no discurso dos agrocombustíveis ocorre, especificamente, com a introdução do biodiesel na matriz energética, vis- $\grave{a}$-vis a tentativa de vincular a agricultura familiar a este setor produtivo. O Programa Nacional de Produção e Uso de Biodiesel - PNPB, que institui o uso obrigatório de biodiesel em todo o país e estabelece metas progressivas de adição de biodiesel ao diesel de petróleo, figura como um programa de inclusão social, pautado na integração da agricultura familiar como fornecedora de matérias-primas (oleaginosas) ao segmento industrial de biodiesel. ${ }^{1}$

\footnotetext{
${ }^{1}$ O Programa Nacional de Produção e Uso de Biodiesel - PNPB - foi lançado em 6 de dezembro de 2004 e regulamentado em 13 de janeiro de 2005, pela Lei n. ${ }^{\circ} 11.097$ (Brasil, 2005a). Com sua adição progressiva, em novembro de 2014 entrou em vigor o B7, mistura obrigatória de $7 \%$ de biodiesel ao diesel de petróleo vendido nos postos.
} 
Desvelando discursos ${ }^{2}$, o presente artigo questiona a justificativa ambiental de promoção dos agrocombustíveis, argumentando acerca dos interesses econômicos e dos fins que norteiam a produção de agroenergia, em sua íntima vinculação com a indústria automobilística. Quanto ao discurso social de promoção do biodiesel que propõe a inserção da agricultura familiar como fornecedora de oleaginosas para produção de combustível, o artigo destaca o perfil produtivo do PNPB em escala nacional, apontando para o predomínio do agribusiness ${ }^{3} \mathrm{em}$ sua cadeia produtiva. Os agrocombustíveis vêm acirrando os conflitos no campo, na medida em que se pautam na monocultura e na apropriação privada e predatória da natureza, obstando outras formas de apropriação dos territórios. Para alcançarmos os propósitos deste artigo, em termos metodológicos, lançamos mão dos dados oriundos da Agência Nacional do Petróleo, Gás Natural e Biocombustíveis
- ANP, da legislação existente para o biodiesel e de literatura pertinente à construção do desvelamento do discurso dos agrocombustíveis no campo $^{4}$ socioambiental.

\section{2. $O$ discurso ambiental e a apropriação mercadológica da problemática do aquecimento global}

O discurso institucional do desenvolvimento sustentável constitui o principal alicerce de justificação da agroenergia nos contextos nacional e internacional. A noção de desenvolvimento sustentável aparece pela primeira vez formalizada em 1987, no relatório Our Common Future, também conhecido como Relatório Brundtland, elaborado pela Comissão Mundial sobre Meio Ambiente e Desenvolvimento Sustentável - CMMAD. ${ }^{5}$ Em 1992, sob forte influência do Relatório Brundtland,

\footnotetext{
${ }^{2} \mathrm{O}$ artigo compartilha da perspectiva teórica que relaciona discurso e poder. O discurso, como prática constituída histórica e socialmente, constitui um elemento de poder, de inserção de noções de verdade na realidade social (Foucault, 2008). Considerando que o discurso é sempre realizado a partir condições de produção específicas e assimétricas inerentes ao social, as estratégias discursivas acionadas pelos agentes nos remetem às relações de poder que buscam instituir verdades (Orlandi, 2001; Foucault, 2008).

${ }^{3}$ Utiliza-se neste artigo os termos agronegócio e agribusiness tal como se constituíram historicamente no Brasil: como uma categoria socioeconômica e política, para designar estritamente os empreendimentos pautados no monocultivo, em grandes extensões de terras, com mecanização e uso intensivo de agroquímicos, devotados à exportação e associados a grandes empresas transnacionais.

${ }^{4}$ A noção de campo está associada à disposição dos atores em relação à distribuição relativa de poder sobre o mundo material e simbólico num espaço de relações conflitivas e lutas classificatórias (Bourdieu, 2003). Como bem explicita Acselrad (2004, p. 18), remetendo-se à teoria social de Pierre Bourdieu, o campo é uma "configuração de relações objetivas entre posições na estrutura de distribuição de diferentes espécies de poder". Assim, o campo configura uma estrutura que se constitui pela relação entre diversas forças que se caracterizam pela heterogeneidade e assimetria, uma vez que há sempre posicionamentos centrais e outros deslegitimados como periféricos.

${ }^{5}$ A necessidade de impor limites ao estilo de vida criado pelo capitalismo industrial se acentua a partir de 1972, quando é publicado, pelo Clube de Roma, o relatório The Limits to Growth, organizado por cientistas do Massachusetts Institute of Technology, liderados por Dennis L. Meadows. As reflexões do Clube de Roma, em tom catastrófico e alarmante, apontavam para a limitação dos recursos naturais (principalmente de origem fóssil), para a tese malthusiana de crescimento geométrico da população mundial e para o paradigma tecnológico que acarretava a aceleração da aproximação dos limites ambientais (Layrargues, 1998). Ainda em 1972, sob forte influência do diagnóstico do Clube de Roma, ocorreu em Estocolmo, na Suécia, a Conferência das Nações Unidas sobre Meio Ambiente Humano, a primeira reunião de caráter oficial a tratar de assuntos ambientais em nível global. A partir desta Conferência, cria-se o conceito de ecodesenvolvimento, expressão da fusão entre desenvolvimento e meio ambiente (e forma embrionária daquilo que mais tarde se consagraria como desenvolvimento sustentável). Na década subsequente à Conferência de Estocolmo, a noção de ecodesenvolvimento entra em desuso e começa a ser substituída pelo conceito de desenvolvimento sustentável (Layrargues, 1998). A definição de desenvolvimento sustentável, instituída em 1987 pela Comissão Brundtland, tão amplamente divulgada e reproduzida, refere-se à competência de garantir que "o desenvolvimento atenda as necessidades do presente sem comprometer a capacidade de as gerações futuras atenderem também às suas” (CMMAD, 1991, p. 46).
} 
realizou-se na cidade do Rio de Janeiro a Conferência das Nações Unidas sobre Meio Ambiente e Desenvolvimento (também denominada Rio-92, Eco-92 ou Cúpula da Terra), na qual a noção de desenvolvimento sustentável foi definitivamente consolidada e difundida. Desde então, o discurso do desenvolvimento sustentável integra as estratégias discursivas do segmento empresarial, além de compor diretrizes das políticas desenvolvimentistas promovidas por agências internacionais, como a Organização das Nações Unidas - ONU, o Banco Mundial e o Fundo Monetário Internacional - FMI (Layrargues, 1998; Zhouri et al., 2005).

Em linhas gerais, a noção de desenvolvimento sustentável visa conciliar progresso econômico e preservação ambiental, apresentando mecanismos para atenuar e gerir os problemas ambientais, a fim de possibilitar a contínua expansão do modelo de desenvolvimento de base urbano-industrial, favorecendo o capital transnacional e financeiro (Layrargues, 1998; Silva, 2000; Acselrad, 2001; Zhouri et al., 2005). No âmbito deste discurso, a justificativa para o fomento da produção de agrocombustíveis encontra-se na problemática ambiental dos combustíveis fósseis, no que concerne à escassez de recursos e às emissões de gases poluentes, causadores do aquecimento global.

A publicação dos alarmantes relatórios sobre o aquecimento global do Intergovernmental Panel on Climate Change - IPCC, em 2007, intensificou o debate sobre a utilização de fontes energéticas não fósseis, visando ao enfrentamento das mudanças climáticas. Nesse contexto, destaca-se a promoção nacional e internacional dos agrocombustíveis, cuja emissão de gases de efeito estufa durante o processo de combustão é apresentada, pela mídia, pelo Estado e pelo mercado, como inferior à dos combustíveis fósseis.

Autores como Porto-Gonçalves (2008), Noble (2009) e Acselrad (2009) revelaram a apropriação da problemática do aquecimento global pelo mercado. Durante anos, as ações políticas foram postergadas frente às incertezas científicas quanto aos efeitos e causas do aquecimento global. Entretanto, observa-se uma mudança na forma de abordagem dessa problemática a partir do momento em que ela é canalizada pelos mecanismos de mercado. Notavelmente, os setores econômicos e políticos que se caracterizaram, a princípio, por desqualificar os argumentos daqueles que denunciavam o aquecimento global passaram a reiterar sua existência (Porto-Gonçalves, 2008). "Entre os recém-convertidos à causa do aquecimento global estão [...] o setor dos grandes produtores de petróleo e o dos grandes latifúndios empresariais de monoculturas que hegemonizam o mundo do agribusiness" (Porto-Gonçalves, 2008, p. 329).

Corroborando essa perspectiva, Noble (2009) explicita a existência de uma "campanha climática corporativa" manifesta pelo surgimento de inúmeras “organizações” estruturadas a partir de alianças empresariais voltadas para a problemática ambiental e, especialmente, para a questão do aquecimento global. ${ }^{6}$ Como integrantes de tais "organizações" destacam-se as grandes empresas transnacionais dos segmentos químico, de petróleo, gás, carvão

\footnotetext{
${ }^{6}$ Entre as “organizações” que surgem a partir de alianças corporativas, Noble (2009) cita: a Pew Center for Global Climate Change (Centro Pew para Mudança Climática), financiada pela Sunoco, empresa petroleira e de gás natural estadunidense; o Business Environmental Leadership Council (Conselho para Liderança Ambiental nos Negócios), estabelecida pelo Pew Center; a Partnership for Climate Action - PCA (Associação para Ações Climáticas), constituída no Fórum Econômico em Davos, Suíça; a U.S Climate Action Partnership - USCAP, entidade de criada pela Pew Center e PCA; e a Alliance for Climate Protection (Aliança para a Proteção Climática), comandada pelo ex-vice-presidente dos EUA, Al Gore.
} 
e de automóveis - a exemplo da Dupont, Beyond Petroleum (antiga British Petroleum) ${ }^{7}$, Shell, Ford, Daimler AG, Texaco, Exxon Mobil, Chevron e General Motors. Tais empresas consideram que as mudanças climáticas devem ser tratadas por meio de "mecanismos de mercado", visando à criação de mercadorias rotuladas de "ecológicas" e de vantagens comparativas pela via do marketing verde (Noble, 2009).

Os segmentos hegemônicos, como o mercado, reconhecem e institucionalizam determinados temas ambientais, funcionalizando-os pro domo sua e evitando questionamentos ao modelo de desenvolvimento imperante na sociedade moderna (Zhouri et al., 2005). O mercado visto como capaz de resolver os problemas socioambientais e a subserviência do Estado aos interesses econômicos compõem o atual cenário de despolitização do debate socioambiental e de precarização das políticas públicas voltadas para o meio ambiente (Acselrad, 2001; Zhouri et al., 2005).

Os agrocombustíveis surgem, portanto, como alternativa econômica, apropriando-se, como justificativa e para legitimação, de discursos do campo ambiental (Layrargues, 1998). Desconstruindo o discurso dos agrocombustíveis como atenuadores das emissão de gases de efeito estufa - GEE, Weid (2009) afirma que ao longo da cadeia produtiva dos agrocombustíveis (desde a obten- ção da matéria-prima no campo à combustão) as emissões de GEE podem ser similares ou mesmo superiores àquelas provenientes do emprego dos combustíveis fósseis. ${ }^{8}$ Ademais, a insustentabilidade dos agrocombustíveis também se evidencia no fomento de monoculturas de cana-de-açúcar e soja, que consomem elevadas quantidades de água, fertilizantes e recursos energéticos, revelando "uma nova bifurcação no interior da "revolução verde"" (Porto-Gonçalves, 2008, p. 350).

Diferentemente do que ocorreu na década de 1970 com o Programa Nacional do Álcool, Proálcool, quando o etanol competia com frações do próprio capital, como aquele ligado à extração e à comercialização do petróleo, as novas configurações econômicas e políticas apontam para uma tendência contrária. ${ }^{9}$ A exemplo da Petrobras Biocombustíveis, subsidiária da Petrobras, criada em 2008 para produção de etanol e biodiesel e da Beyond Petroleum - BP, os investimentos no desenvolvimento e na produção de agroenergia são expressivos e revelam articulações do segmento petroleiro com setores da indústria automobilística e do agribusiness. Logo, a inserção das petroleiras no mercado de agrocombustíveis deve ser analisada não apenas como uma possibilidade de abocanhar um novo nicho de mercado, mas também como uma estratégia global para prolongar, a qualquer custo social e ambiental, o pico do petróleo.

\footnotetext{
${ }^{7}$ A BP, multinacional britânica, é considera uma das maiores empresas exploradoras, refinadoras e distribuidoras de petróleo e gás do mundo. Ao fundir-se com a American Oil Company - Amoco e adquirir a Atlantic Richfield Company - ARCO, em 1999, e a Burmah Castrol, em 2000, a BP mudou a sua logomarca, unificando as quatro companhias. A nova logomarca, Beyond Petroleum (que pode ser traduzido como "além do petróleo"), expressa a proposta da empresa de explorar novas energias.

${ }^{8}$ A emissão de gases do aquecimento global decorre da própria utilização de petróleo ao longo da cadeia de produção dos agrocombustíveis; da utilização de agroquímicos (derivados do petróleo); do desmatamento para expansão das culturas agroenergéticas; da utilização de grandes quantidades de água e energia em sistemas de irrigação e transporte e da fertilização com fontes nitrogenadas (o que ocasiona o aumento da emissão de $\mathrm{N}_{2} \mathrm{O}$, cujo potencial de aquecimento global é 296 vezes superior ao do $\mathrm{CO}_{2}$ ) (Weid, 2009).

${ }^{9}$ A conjuntura dos anos 70, quando o governo brasileiro incentiva o uso do etanol, é diferente da atual conjuntura de incentivo à produção de agrocombustíveis. O Proálcool foi concebido e executado como uma solução emergencial, provisória, para a crise de suprimento de gasolina (dada às crises do petróleo de 1973 e de 1979), e não como um componente de uma estratégia econômica global, tal como são hoje os agrocombustíveis.
} 
No caso da BP, podemos destacar o fornecimento de uma enorme quantia (aproximadamente 500 milhões) para fundos de pesquisa, para a Universidade de Berkeley, para o Laboratório Nacional de Lawrence Livermore e para a Universidade de Illinois, para o desenvolvimento de, principalmente, biotecnologia voltada para a produção de agrocombustíveis (Altieri \& Holt-Gimenez, 2007). Segundo Holleman \& Clausen (2008), a articulação da Universidade de Berkeley, uma instituição pública, com a BP é considerada uma das maiores alianças acadêmico-industriais na história dos Estados Unidos para atender a finalidades estritamente privadas.

Nessa perspectiva, podemos citar ainda a conformação de articulações intersetoriais entre a BP e a Toyota para produção de etanol no Canadá a partir de celulose extraída de resíduos, bem como entre a Volkswagen e o conglomerado do setor de alimentos Archer Daniels Midland Company-ADM, além do ingresso da Shell na geração de agrocarburantes e da "Cargill, outra grande multinacional do setor agroalimentar, [...] na produção de diesel vegetal" (Guillet, 2007 apud Porto-Gonçalves, 2008, p. 344).

Outros atores-chave na cadeia produtiva dos agrocombustíveis são as empresas especializadas no ramo de sementes, como a Monsanto, a Syngenta e a Dupont (Altieri \& Holt-Gimenez, 2007). Tal interesse explica-se pela oportunidade de transformar a agricultura em plantações geneticamente modificadas, ou melhor, "laboratorialmente modificadas" ", sob a alegação de que são para produção de combustível e não para alimentação humana (Altieri \& Holt-Gimenez, 2007). Com efeito, por meio da agroenergia, as grandes empresas de sementes "laboratorialmente modificadas" logram não ape- nas mercado, mas também legitimidade social, ao difundirem os produtos transgênicos como fontes de energia "limpa".

O novo bloco de poder formado em torno dos agrocombustíveis aponta para um alinhamento global corporativo dos maiores do mundo no âmbito do agronegócio (ADM, Bunge e Cargill), das biotecnologias (Monsanto, Syngenta, Bayer, Dupont), petróleo (BP, Petrobras, Shell) e das indústrias automotoras (Volkswagen, Peugeot, Toyota, Renault) (Altieri \& Holt-Gimenez, 2007). Conforma-se, portanto, em torno dos agrocombustíveis um “complexo de poder técnico-científico-industrial-financeiro-midiático” (Porto-Gonçalves, 2008).

\section{Indústria automobilística: o motor dos agrocombustiveis}

O modelo industrial do século XX desenvolveu-se calcado nas energias fósseis, indispensáveis ao padrão de acumulação fordista, implementado na e a partir da indústria automobilística. O setor que mais consome combustíveis fósseis é o de transportes, que responde por cerca da metade do consumo interno de derivados de petróleo no Brasil (Ludd, 2004). Os veículos motorizados são também considerados grandes geradores de poluição atmosférica, "contribuindo estimadamente com 14\% das emissões mundiais de dióxido de carbono provenientes da queima de combustível fóssil" (Ludd, 2004, p. 129). Nesse contexto, as indústrias automobilísticas argumentam que a solução para a redução da poluição atmosférica provocada pelos veículos está no desenvolvimento de motores mais eficazes e na utilização de agrocombustíveis.

\footnotetext{
${ }^{10}$ Porto-Gonçalves (2008) utiliza o termo organismos laboratorialmente modificados - OLMs - ao invés de organismos geneticamente modificados - OGMs, para tornar explícito seu caráter industrial, já que toda evolução de espécies implica modificações genéticas, inclusive, pela relação da agricultura com a natureza.
} 
Estimulado por políticas públicas e em conformidade com o sistema de peritos (expert sistems), atrelado ao complexo técnico-industrial, o mercado de agrocombustíveis vem se firmando sob o baluarte da energia limpa (Lages \& Penido, 2009). O discurso técnico, em sua relação com o discurso ambiental hegemônico, apresenta-se como capaz de "resolver" os problemas ambientais na esfera do mercado. Entretanto, analisar a sustentabilidade dos agrocombustíveis implica elucidar a natureza dos fins que norteiam sua produção, voltada para o abastecimento de veículos automotores.

Inegavelmente, a indústria automobilística figura como lócus-chave da expansão do capital. O desenvolvimento do setor de transportes propiciou a redução do tempo de retorno do capital ao "comprimir" distâncias. A massificação dos veículos automotores e a densa rede viária e rodoviária possibilitaram a expansão da cidade e sua articulação em rede-elementos indispensáveis para a reprodução sempre ampliada do capital. Ademais, a cadeia produtiva capitaneada pela indústria automobilística possui um caráter econômico e político estratégico pela gama de indústrias que abarca: mineração, metalurgia, plástico, autopeças, material elétrico, petróleo, agrocombustíveis, junto com indústrias de apoio como empreiteiras, segmentos de publicidade e financeiro (Aufheben, 2004).

Ivan Illich evidencia a insustentabilidade dos veículos automotores, como questão energética nas sociedades industriais. $\mathrm{Na}$ construção de uma crítica radical do modo industrial de produção e de consumo, Illich (2004) afirma que os veículos automotores conduzem processos de reestruturação urbana, ao mesmo tempo em que o rumo tomado pelo crescimento das cidades impõe a necessidade supostamente inelutável do transporte motorizado. Ironicamente, a máquina que é vendida por sua capacidade de superar distâncias cria tanta distância quanto atravessa (pela produção de espaços projetados totalmente em função do carro) e desperdiça mais tempo do que economiza ${ }^{11}$ (Illich, 2004; Control, 2004; Gorz, 2004), evidenciando o que Illich denomina de contraprodutividade.

Ademais, os veículos automotores, ao produzirem distâncias que só eles podem reduzir, aumentam o consumo de recursos energéticos, apontando para um limiar ecológico contraprodutivo, já que ambientalmente insustentável (Illich, 2004). Cria-se, pois, uma dependência em relação à indústria automobilística, que parte de uma concepção de desenvolvimento realizada em nome de uma "ideologia de consumo indefinido de energia" (Illich, 2004). Nas palavras do autor, essa dependência se institui "quando a sociedade se adapta aos fins daqueles que consomem uma quantidade maior de energia" e se enraíza irreversivelmente quando impõe "a todos a obrigação de consumir o quantum mínimo sem o qual a máquina [mundial] não pode funcionar" (Illich, 2004, p. 57).

Entretanto, cabe ainda destacar que a possibilidade de superar e reduzir distâncias figura como privilégio de quem pode pagar pela energia necessária à sua realização, revelando a contradi-

\footnotetext{
${ }^{11}$ Illich (2004, p. 53) subverte: ao diminuir o tempo necessário para cobrir $1.000 \mathrm{~km}$, reduz-se também o tempo que poderia ser empregado em outra atividade que não o deslocamento. "Um americano típico consagra mais de 1.600 horas por ano ao seu automóvel - sentado dentro dele, andando ou parado, trabalhando para pagá-lo e para pagar a gasolina, os pneus, os pedágios, o seguro, as multas e os impostos para as estradas federais e para os estacionamentos públicos. Consagra a ele quatro horas por dia, nas quais se serve dele, se ocupa dele ou trabalha para ele" (Illich, 2004, p. 45). Ademais, deve-se considerar o tempo gasto em engarrafamentos. De acordo com Limoncic (2000), em São Paulo, por exemplo, os paulistanos perdem 316 milhões de horas/ano em congestionamentos severos.
} 
ção entre equidade e energia automotora (Illich, 2004). Desta forma, para Illich (2004, p. 37), crer na possibilidade de consumo de "energia limpa" como solução para todos os males representa "um erro de juízo político". "É imaginar que a equidade na participação do poder e o consumo de energia podem crescer juntos" (Illich, 2004, p. 37). Ou seja, o consumo intensivo de energia contraria, em si, o princípio da equidade, de forma que ambos não podem crescer no mesmo ritmo indefinidamente, pois a base de recursos naturais existente simplesmente não suportaria.

Nessa linha de abordagem, não podemos deixar de considerar que o consumo intensivo de energia torna qualquer discurso sobre sustentabilidade (independentemente da fonte energética) questionável, já que a utilização intensiva, inclusive dos recursos ditos "renováveis", conduz à sua exploração destrutiva. Aqui, o uso da noção de equidade, além de questionar as assimetrias no acesso e na repartição dos recursos naturais e energéticos, deve atentar para a distribuição desigual dos riscos ${ }^{12}$ e danos ambientais decorrentes da exploração da natureza que, via de regra, recaem sobre os grupos sociais e etnias mais vulneráveis.

Outrossim, no próprio processo de fabricação dos veículos automotores gasta-se grande quantidade de energia e recursos naturais, em função da utili- zação de aço, ferro, borracha, plásticos e alumínio, além da geração de poluição oriunda dos procedimentos industriais (Ludd, 2004). Logo, "um carro gera mais poluição antes mesmo de ser dirigido do que em sua vida inteira de uso" (Ludd, 2004, p. 131).

Em outros termos, a poluição automotiva persiste independente do tipo de combustível utilizado, se fóssil ou agrocombustível. Segundo Ludd (2004), cerca de $60 \%$ da poluição não provém do uso do carro, mas começa antes mesmo do processo de fabricação e continua após o descarte do veículo. Desde os anos 1920, a criação por Alfred Sloan, então presidente da General Motors, do chamado "carro do ano" impulsiona o consumo e, por conseguinte, o processo de produção, cumprindo as exigências de aceleração dos ciclos reprodutivos do capital (Martins, 2010).

A crescente demanda por veículos (e, consequentemente, por combustíveis) é estimulada, no Brasil, por políticas de redução de Impostos sobre Produtos Industrializados - IPI - para aquisição de automotivos novos (carros e caminhões) e pela facilidade de créditos e financiamentos. Justificadas como forma de driblar a crise econômica e manter o plano de vendas da indústria automobilística, tais políticas implicam o aumento da quantidade de emissões de gases poluentes, já que a tendência induzida é sempre de aumento da frota em circulação.

\footnotetext{
12 Ulrich Beck $(1998 ; 2010)$ trata da emergência da "sociedade de risco" como produto da modernidade e de sua razão instrumental. Nas sociedades industriais modernas, os riscos da modernização, ou seja, os efeitos negativos do progresso, recaem sobre os sujeitos sem distinções de classe e não são limitáveis no espaço (Beck, 1998; 2010), como é o caso dos efeitos do aquecimento global. Os riscos "são fabricados de forma industrial, exteriorizados economicamente, individualizados no plano jurídico, legitimados no plano das ciências exatas, e minimizados no plano político" (Beck, 2010, p. 230). Normalizados e em constante progressão, os riscos são negados ou dissimulados a fim de "impedir o estabelecimento das relações de causa e efeito, ou, de maneira mais geral, de responsabilidades”. Contraditoriamente, tais riscos servem à própria valorização do capital, já que "a sociedade industrial produz com o aproveitamento econômico dos riscos induzidos por ela [...]" (Beck, 1998, p. 29). Assim, a questão do aquecimento global, a necessidade de energias renováveis e a escassez e poluição de combustíveis fósseis dão nova legitimidade aos agrocombustíveis. Entretanto, cabe destacar que, embora alguns riscos sejam distribuídos globalmente ou independentemente de classe social, há uma relação inegável entre desigualdade social e ambiental, explicitada pelas noções de injustiça e racismo ambiental (Acselrad; Pádua \& Herculano, 2004), já que determinados danos e riscos recaem, não raro, sobre populações historicamente subalternizadas (como, por exemplo, moradores das periferias urbanas, submetidos à poluição industrial de alto risco, ou, ainda, comunidades rurais, indígenas e quilombolas, atingidas por grandes empreendimentos econômicos, como hidrelétricas, monoculturas e megaminerações).
} 


\section{A geopolítica dos agrocombustíveis}

No contexto mundial, Estados Unidos e Brasil são os maiores produtores de etanol do mundo - o primeiro com cerca de 50 bilhões de litros, produzidos à base de milho, e o segundo, com 27,7 bilhões de litros, produzidos à base de cana-de-açúcar (EPE, 2014).

Todavia, se os Estados Unidos destinarem toda a produção atual de milho e soja para a produção de agrocombustíveis, só satisfariam $12 \%$ da demanda por gasolina e $6 \%$ da demanda por diesel (Altieri \& Holt-Gimenez, 2007). Logo, para substituir o consumo de petróleo nos Estados Unidos por etanol e biodiesel seriam necessárias, respectivamente, 1,4 milhão de milhas quadradas de milho e 8,8 milhões de milhas quadradas de soja (Altieri \& Holt-Gimenez, 2007).

A alta demanda de agrocombustíveis dos Estados Unidos e da Europa, assim como a necessidade de expansão geográfica de capitais internacionais "sobreacumulados" (Harvey, 2005), tendem a fomentar a expansão de monoculturas agroenergéticas em países da América Latina, do Caribe, da Áfri$\mathrm{ca}^{13}$ e do Sudeste Asiático (Leroy, 2007; Altieri \& Holt-Gimenez, 2007; Laschefski, 2010). Logo, as culturas utilizadas para geração de combustíveis são produzidas "nos países em vias de desenvolvimen- to, por plantações em grande escala" de cana-de-açúcar, soja e palmáceas, que vêm "substituindo florestas tropicais primárias e secundárias e pastos na Argentina, Brasil, Colômbia, Equador e Malásia" (Altieri \& Holt-Gimenez, 2007, n.p.).

A demanda por agroenergia estendida a outros países do mundo (uma demanda global, como se pretende) implicaria o estabelecimento de novas relações geopolíticas, a partir da possível criação de "novas raridades" ${ }^{14}$ manifestas em espaços que conjugam fatores potenciais para a produção de biomassa, a saber: clima tropical, água em abundância e grandes extensões de terras apresentadas como "disponíveis". ${ }^{15}$ Como adverte Altvater (1995, p. 95), apesar de sua dimensão continental, "o espaço geográfico é tão limitado quanto o são as ricas jazidas de recursos naturais".

Para Laschefski (2010), as relações diplomáticas que se estabelecem em torno dos agrocombustíveis e a busca por novas áreas de influência sobre regiões produtoras (ou com potencial de produção) de agroenergia podem revelar o surgimento de um "novo imperialismo" (Harvey, 2005) de caráter dissimulado, fundamentado nos mecanismos da globalização econômica de cunho neoliberal. Entretanto, a geopolítica que desponta com os agrocombustíveis mostra que as formas aparentemente abstratas de poder (como, por exemplo, as influên-

\footnotetext{
${ }^{13}$ Em países da África, em 2011, o The Guardian contabilizou pelo menos 3,2 milhões de hectares de plantações para agrocombustíveis destinadas a empresas estrangeiras, principalmente britânicas (Bellacosa, 2012, p. 181). Somente a empresa inglesa Crest Global Green Energy detém 900 mil hectares em três países africanos (Bellacosa, 2012, p. 181).

${ }^{14}$ Se outrora o pão, os meios de subsistência eram raros, "agora, não em todos os países, mas virtualmente à escala planetária, há uma produção abundante desses bens; não obstante, as novas raridades, em torno das quais há luta intensa, emergem: a água, o ar, a luz, o espaço" (Lefebvre, 2008, p. 66-67). Trata-se de uma "sociedade de raridades", princípio básico da economia política, cujo sentido e raridade (das mercadorias) vão mudando ao longo do processo de reprodução social, impulsionados pela valorização econômica. Ou seja, as "novas raridades" são também produzidas como raridade, sendo resultado/corolário da matriz técnico-científica associada a uma dada concepção de progresso/desenvolvimento.

${ }^{15}$ Entre as vantagens competitivas do Brasil no setor agroenergético, é mencionada a disponibilidade de 90 milhões de hectares para a expansão agrícola, o que representa cerca de $22 \%$ da área possível de ampliação da agricultura mundial (Faleiros, 2008). Contudo, as áreas ditas disponíveis, não raro, são terras ocupadas por populações tradicionais em ecossistemas preservados.
} 
cias diplomáticas) necessitam de uma base material para se fundar (Harvey, 2005). Espacialidade que, com suas consequências, muitas vezes, é denegada e mascarada no contexto das regras constitutivas da globalização neoliberal e do sistema dominante das relações internacionais.

Conforme David Harvey (2005, p. 117), o "novo imperialismo" se manifesta na abertura (forçada ou não) dos países e territórios ao comércio internacional, assim como na permissão irrestrita de investimentos do capital para obtenção incondicional de lucro por meio, por exemplo, da troca desigual entre países, das relações de dependência econômica e da exploração da força de trabalho, de matérias-primas, e da terra a baixo custo por empresas transnacionais.

De uma forma velada ou mais aberta, conforme as circunstâncias, tanto os Estados Unidos quanto a Europa - em razão de seu poderio econômico e de sua influência em algumas importantes organizações financeiras internacionais, como o FMI e o Banco Mundial - continuaram a exercer considerável controle sobre determinadas nações chamadas subdesenvolvidas, mesmo após sua independência política formal (Harvey, 2005). De fato, o poder econômico (na prática de embargos comerciais e na ação das organizações financeiras internacionais, por exemplo) pode ser usado com efeitos tão destrutivos quanto os da força física (Harvey, 2005).

Nesses termos, Harvey afirma a relação entre a reprodução expandida, de um lado, e os processos muitas vezes violentos de espoliação, do outro, no que ele designa como "acumulação por espoliação". ${ }^{16}$ Para o autor, o "veículo primário" da $a c u$ mulação por espoliação encontra-se na "abertura forçada de mercados em todo o mundo mediante pressões institucionais exercidas por meio do FMI e da OMC" (Harvey, 2005, p. 147).

Nesse cenário marcado pelo domínio do mercado, organizações financeiras internacionais atuam lado a lado com os países ditos desenvolvidos e com as grandes corporações transnacionais, agindo para preservar as assimetrias entre países, de forma a auferir vantagens para os interesses capitalistas dominantes. Os agrocombustíveis, na linha da globalização neoliberal, apresentam-se pautados na articulação intersetorial de grandes conglomerados transnacionais, subsidiados pelas políticas governamentais, com o intuito de inserir, principalmente, os países "periféricos", notadamente latino-americanos, caribenhos e africanos, nos circuitos produtivos.

Em termos geopolíticos, há que se considerar também que os agrocombustíveis envolvem o cerne da política energética, considerada estratégica para qualquer projeto de poder de caráter nacionalista ou imperialista (Maricato, 2008). Aqui, as alianças entre os setores petrolífero, automobilístico e do agronegócio, com forte investimento tecnológico, expressam um realinhamento das relações de poder em favor da difusão dos agrocombustíveis, com a inserção de novas forças na trama geopolítica (Porto-Gonçalves, 2008).

\footnotetext{
${ }^{16} \mathrm{O}$ termo "acumulação por espoliação", utilizado por Harvey, faz referência às práticas predatórias de acumulação primitiva ou original no domínio da geografia histórica da acumulação do capital. Entretanto, “como parece estranho qualificar de 'primitivo' ou 'original' um processo em andamento", o autor substitui esses termos pelo conceito de "acumulação por espoliação" (Harvey, 2005, p. 121). Todavia, "acumulação primitiva" e "acumulação por espoliação" não são termos sinônimos, já que esta última compõe novas formas de acumulação, reproduzidas sob a égide da globalização neoliberal, como forma de resolver os problemas da sobreacumulação, podendo ser ainda mais destrutiva que a acumulação primitiva (Harvey, 2005, p. 127).
} 
No âmbito das relações diplomáticas e das novas configurações de poder que estão se articulando em torno dos agrocombustíveis, assume um caráter emblemático o Memorando de Entendimento sobre a Cooperação na Área de Biocombustiveis, assinado em março de 2007 entre Brasil e EUA. Os presidentes na época, George W. Bush e Luís Inácio Lula da Silva, passaram a se apresentar "como ambientalmente preocupados" no momento em que "o argumento ecológico pôde justificar lucros para os capitais, divisas para o equilíbrio monetário [e] promessa de empregos para os eleitores [...]" (Acselrad, 2009, p. 73).

O referido Memorando sela a intenção de cooperação para a expansão tecnológica e econômica dos agrocombustíveis no nível mundial, com o estímulo à produção de agrocombustíveis em diversos países. Em março em 2011, ampliando este memorando, foi firmada uma parceria entre Brasil e EUA no desenvolvimento de agrocombustível para aviação (bioquerosene) (MME, 2011). Nesse quadro, os agrocombustíveis são apresentados (na aliança econômica e midiática entre Lula e Bush) como solução para a pobreza, como forma de geração de renda, inclusão social e desenvolvimento, sobretudo, para os chamados países subdesenvolvidos, o que resulta na inexorabilidade de expansão dos cultivos agroenergéticos. A exemplo, no discurso proferido por Luís Inácio Lula da Silva, quando do encontro com o então presidente dos Estados Unidos, George Bush, o uso crescente de biocombustíveis

[...] será uma contribuição inestimável para a geração de renda, inclusão social e redução da pobreza em muitos países pobres do mundo. Queremos ver as biomassas gerarem desenvolvimento sustentável, sobretudo na América do Sul, na América Central, no Caribe e na África (Discurso de Luís Inácio Lula da Silva, em 9 de março de 2007. Folha Online, 2007).

A divisão internacional do trabalho então instituída aponta para relações historicamente estabelecidas, no chamado "sistema-mundo-moderno-colonial", que, no exercício da colonialidade do poder (Lander, 2005), ainda mantém os países latino-americanos, caribenhos e africanos como produtores de matéria-prima e energia necessárias à manutenção dos níveis de acumulação dos países ditos "desenvolvidos" (Assis, 2008). Logo, via espoliação ecológica, a riqueza e o bem-estar dos "países desenvolvidos" e de particulares aumentam à custa da utilização de recursos naturais "subvalorizados" de outros territórios (Martinez-Alier, 1999). Como resultado, agravar-se-iam os conflitos ambientais ${ }^{17}$, transferindo para as nações do Terceiro Mundo os custos para se produzir energia e os impactos socioambientais da expansão de monoculturas agroenergéticas.

\section{O domínio do agribusiness no Programa Nacional de Produção e Uso de Biodiesel - PNPB}

Desde a década de 1970, com o Proálcool, o modelo de produção de agrocombustíveis vem se pautando na monocultura, no latifúndio e no agribusiness, atrelado a grandes grupos de interesse (dentre os quais os usineiros de álcool/açúcar e os grandes fabricantes de equipamentos). No início do

\footnotetext{
${ }^{17}$ Os conflitos ambientais são "aqueles envolvendo grupos sociais com modos diferenciados de apropriação, uso e significação do território, tendo origem quando pelo menos um dos grupos tem a continuidade das formas sociais do meio que desenvolvem ameaçada por impactos indesejáveis [...] decorrentes do exercício das práticas de outros grupos" (Acselrad, 2004, p. 26).
} 
século XXI, o Brasil voltou a ser um grande consumidor de etanol "devido à adoção da tecnologia flex-fuel nos motores dos automóveis, que permite a mistura de gasolina e álcool em qualquer proporção" (Schlesinger, 2008, p. 9). A monocultura de cana-de-açúcar ocupa uma área de 8.954,8 mil hectares no Brasil (CONAB, 2015b) e tem exacerbado os conflitos no campo, deflagrando processos de expropriação de comunidades rurais, conflitos por terra, diminuição da produção de alimentos, êxodo rural, desmatamento, perda da biodiversidade e violação dos direitos humanos e trabalhistas (Assis \& Zucarelli, 2007; Schlesinger, 2008).

Embora a produção de biodiesel, via PNPB, possua um discurso de forte apelo social, em função da integração da agricultura familiar como fornecedora de matéria-prima, o programa não foge ao modelo de desenvolvimento agrícola vigente, que valoriza a mecanização, o uso de agrotóxicos, a monocultura, o latifúndio e o agronegócio (Penido, 2011). O Governo Federal lançou o PNPB em 2004, atribuindo ao mercado a função de inserir a agricultura familiar ${ }^{18}$ na cadeia produtiva do biodiesel, em troca da concessão do Selo Combustível Social.

Concedido pelo Ministério do Desenvolvimento Agrário - MDA, o Selo Combustivel Social, além de fornecer à usina de biodiesel o título de "promotora da inclusão social dos agricultores familiares" (Brasil, 2014), proporciona: 1) o reconhecimento das condições requeridas para desfrutar de incentivos fiscais, como alíquotas diferenciadas de PIS/
PASEP e COFINS; 2) o acesso a melhores condições de financiamento junto ao Banco Nacional de Desenvolvimento Econômico e Social - BNDES - e outras instituições financeiras (como, por exemplo, o Banco da Amazônia S/A. - BASA, o Banco do Brasil S/A. e o Banco do Nordeste do Brasil - BNB); e 3) o direito à concorrência nos leilões de biodiesel da ANP (Penido, 2011). Cabe destacar que, mais que os incentivos tributários, a participação nos leilões da ANP é o grande motivador para a aquisição do Selo Combustivel Social, já que só através do Selo é possível participar dos leilões e, por conseguinte, comercializar o biodiesel produzido. ${ }^{19}$

Entretanto, embora no discurso de promoção do biodiesel este esteja atrelado à agricultura familiar, uma análise de seu perfil produtivo em escala nacional revela o domínio do agribusiness em sua cadeia produtiva. Conforme dados de julho de 2015, o óleo de soja $(82,43 \%)$ e o sebo bovino $(16,01 \%)$ respondem por $98,44 \%$ das matérias-primas utilizadas para produção de biodiesel (os 1,56\% restantes correspondem a matérias-primas diversas, como óleo de algodão, dendê/palma, óleo de fritura, gordura de porco, de frango, etc.) (ANP, 2015). Embora a porcentagem dessas matérias-primas varie mensalmente, conforme podemos observar pelos boletins mensais da ANP, o acompanhamento da série histórica da produção de biodiesel evidencia, invariavelmente, o predomínio da soja e do sebo bovino.

Não obstante a baixa eficiência energética da soja (baixo conteúdo de óleo, estimado em 17\% por

\footnotetext{
${ }^{18}$ O PNPB e a legislação relativa ao biodiesel pautam-se na definição de agricultor familiar da Lei no 11.326 , de 24 de julho de 2006 (Brasil, 2006) e consideram como agricultor familiar aquele que possui a Declaração de Aptidão ao Pronaf - DAP, documento que identifica os beneficiários do Programa Nacional de Fortalecimento da Agricultura Familiar - Pronaf.

${ }^{19} \mathrm{O}$ leilão é dividido em dois lotes (duas fases). O primeiro lote é realizado para suprir $80 \%$ da demanda projetada de biodiesel, conforme o percentual de mistura de biodiesel ao diesel, previsto em lei. Só podem participar da primeira fase do leilão os produtores de biodiesel que possuem o Selo Combustível Social. Nessa fase, o volume de biodiesel ofertado é muito maior que na segunda fase (segundo lote). Os leilões são concorridos, porque a capacidade instalada das usinas de biodiesel encontra-se acima da demanda (informações fornecidas em entrevista realizada em maio de 2010 com o Gerente Geral da Usina Darcy Ribeiro, da Petrobras Biocombustíveis, em Montes Claros/MG).
} 
Garcia e Romeiro, 2010), sua produção em larga escala (movida, principalmente, pela produção de torta e farelo para alimentação animal, diretamente ligada à maior demanda por carne no mercado mundial) favorece a reprodução de sua condição de principal matéria-prima para produção de biodiesel (Schlesinger \& Noronha, 2006).

$\mathrm{Na}$ escala mundial, o Brasil é o segundo maior produtor de soja, com produção estimada em 96.203,5 mil toneladas e uma área plantada de 31.940,3 mil hectares (CONAB, 2015a). As regiões Centro-Oeste e Sul lideram o ranking da produção de soja no país, com respectivamente 44.201,1 mil toneladas $(45,95 \%$ da produção nacional) e $33.831,2$ mil toneladas $(35,17 \%$ da produção nacional) (CONAB, 2015a). O Estado do Mato Grosso figura como o maior produtor nacional, com 28.133,8 mil toneladas, seguido pelo Estado do Paraná, com 17.123,5 mil toneladas (CONAB, 2015a).

Segundo dados da ANP (2015), existem 56 plantas produtoras de biodiesel autorizadas pela
ANP em operação no país, correspondendo a uma capacidade total autorizada de $20.872,51 \mathrm{~m}^{3} /$ dia. Não por acaso, o Centro-Oeste concentra o maior número de produtores de biodiesel (25 usinas), sendo que 17 delas estão localizadas no Mato Grosso, estado que, vale lembrar, integra a Amazônia Legal. O Sul figura como a segunda região com maior número de usinas (14 usinas), seguido pela região Sudeste (10 usinas) (vide Tabela 1).

Como se pode constatar, $87,5 \%$ das 56 usinas de biodiesel existentes no Brasil encontram-se localizadas no centro-sul do país, com destaque para as regiões Centro-Oeste (44,64\% das usinas) e o Sul (25\% das usinas), que lideram o ranking de produção de soja, como vimos, a principal matéria-prima para produção de biodiesel.

Embora os boletins mensais da ANP não divulguem a origem da soja adquirida (se advém da agricultura familiar ou do agribusiness), a participação da agricultura familiar na cadeia produtiva de biodiesel vem se limitando às pequenas porcentagens

TABELA 1 - Quantidade de produtores de biodiesel por região e por estado.

\begin{tabular}{|c|c|c|c|}
\hline Regiões geográficas & $\mathrm{N}^{0}$ de produtores por região & Estados Federados & $\mathrm{N}^{0}$ de produtores por Estados \\
\hline \multirow{2}{*}{ Norte } & \multirow{2}{*}{3} & Rondônia & 1 \\
\hline & & Tocantins & 2 \\
\hline \multirow{3}{*}{ Centro-Oeste } & \multirow{3}{*}{25} & Goiás & 6 \\
\hline & & Mato Grosso & 17 \\
\hline & & Mato Grosso do Sul & 2 \\
\hline \multirow{3}{*}{ Nordeste } & \multirow{3}{*}{4} & Bahia & 2 \\
\hline & & Rio Grande do Norte & 1 \\
\hline & & Ceará & 1 \\
\hline \multirow{3}{*}{ Sudeste } & \multirow{3}{*}{10} & Minas Gerais & 3 \\
\hline & & Rio de Janeiro & 1 \\
\hline & & São Paulo & 6 \\
\hline \multirow{3}{*}{ Sul } & \multirow{3}{*}{14} & Paraná & 4 \\
\hline & & Rio Grande do Sul & 9 \\
\hline & & Santa Catarina & 1 \\
\hline TOTAL & 56 & & \\
\hline
\end{tabular}

FONTE: Elaborada pela autora com base nos dados do Boletim Mensal do Biodiesel da ANP, julho 2015. 
exigidas dos industriais de biodiesel para aquisição do Selo Combustivel Social (Penido, 2011).

Para obtenção do Selo, conforme a Portaria n. ${ }^{\circ}$ 81 , de novembro de 2014, o produtor industrial de biodiesel deverá investir na aquisição de matérias-primas de origem vegetal advindas da agricultura familiar: 1) $15 \%$ para as aquisições provenientes das regiões Norte e Centro-Oeste; 2) 30\% para as aquisições provenientes das regiões Sudeste, Nordeste e Semiárido; e 3) 40\% para as aquisições provenientes da região Sul (vide tabela 2) (Brasil, 2014). Estes percentuais são calculados "sobre o custo de aquisição da matéria-prima adquirida do agricultor familiar ou de sua cooperativa agropecuária em relação ao custo de aquisições totais de matérias-primas utilizadas no período para a produção de biodiesel" (Brasil, 2009). ${ }^{20}$

Como podemos observar na Tabela 2 , a maior participação da agricultura familiar na cadeia produtiva do biodiesel ocorre na região Sul do País. No Sul, diferentemente das demais regiões brasileiras, predomina a participação da agricultura familiar no cultivo de soja (Schlesinger, 2008). De acordo com dados de 2010 da Secretaria da Agricultura Familiar do Ministério de Desenvolvimento Agrário, a soja
TABELA 2 - Participação mínima da agricultura familiar entre os fornecedores de matéria-prima para obtenção do Selo Combustivel Social.

\begin{tabular}{lcc}
\hline \multicolumn{1}{c}{ Região } & $\begin{array}{c}\text { Participação } \\
\text { da Agricultura } \\
\text { familiar (\%) }\end{array}$ & $\begin{array}{c}\text { Participação da } \\
\text { Agricultura } \\
\text { Patronal (\%) }\end{array}$ \\
\hline $\begin{array}{l}\text { Norte } \\
\text { Nordeste e Semiárido }\end{array}$ & $15 \%$ & $85 \%$ \\
(Norte de Minas) & $30 \%$ & $70 \%$ \\
Centro-Oeste & $15 \%$ & $85 \%$ \\
Sudeste & $30 \%$ & $70 \%$ \\
Sul & $40 \%$ & $60 \%$ \\
\hline
\end{tabular}

FONTE: Elaborada pela autora com base na Portaria n. ${ }^{\circ} 81$, de 2014.

* A participação mínima da agricultura familiar inclui em suas porcentagens o mínimo de gastos que a usina de biodiesel deve ter com a agricultura familiar (não só com a compra de matéria-prima, mas também com assistência técnica, doação de sementes e sacaria, por exemplo). Ou seja, esta participação, em termos de matériaprima em si é, ainda, muito menor.

representa 95,20\% das aquisições da agricultura familiar (em reais) realizadas pelos industriais do biodiesel (SAF/MDA, 2011). Ainda conforme esta Secretaria, cerca de 50 mil agricultores familiares no Sul do País participavam em 2010 do PNPB, o que desde já aponta para a origem geográfica da soja adquirida da agricultura familiar (SAF/MDA, 2011). ${ }^{21}$ Conforme analisado por Penido (2011), o

\footnotetext{
${ }^{20}$ Segundo o artigo $4^{\circ}$ da Portaria n. ${ }^{\circ} 81$, de novembro de 2014, o custo de aquisição de matérias-primas da agricultura familiar foi definido como o somatório dos seguintes itens: 1) valor de aquisição da matéria-prima; 2) valor das despesas com análise de solos de propriedades familiares; 3) valores referentes à doação dos insumos de produção e serviços aos agricultores familiares, desde que não oriundos de recursos públicos, limitados aos seguintes itens: a) sementes e/ou mudas; b) adubos; c) corretivo de solo; e d) horas-máquina e/ou combustível; e) sacaria; f) máquinas, equipamentos e benfeitorias ligadas à atividade agrícola ou agroindustrial para produção de matérias-primas, doados para cooperativas agropecuárias habilitadas, ou associações legalmente constituídas de agricultores contratados; 4) valor referente à assistência e capacitação técnica dos agricultores familiares, limitando-se aos seguintes itens: a) salários e/ou honorários dos técnicos contratados diretamente pelas empresas produtoras de biodiesel, inclusos os encargos trabalhistas; b) despesas de deslocamento, hospedagem, material didático e alimentação para a realização da assistência técnica e capacitação aos agricultores familiares e de sua capacitação, limitadas ao valor máximo de $40 \%$ em relação ao valor do pagamento de salário e/ou honorários dos técnicos contratados diretamente pela empresa; c) pagamento à instituição prestadora deste serviço, quando terceirizado pelo produtor de biodiesel, limitado a salários e/ou honorários dos técnicos inclusos os encargos trabalhistas, e despesas de deslocamento, hospedagem, material didático e alimentação para a realização da assistência técnica e capacitação aos agricultores familiares, limitadas ao valor máximo de 40\% em relação ao valor do pagamento de salário e/ou honorários dos técnicos (Brasil, 2014).

${ }^{21}$ As informações da Secretaria de Agricultura Familiar - SAF - do Ministério do Desenvolvimento Agrário - MDA - foram retiradas da apresentação do MDA, na Reunião Internacional “Biodiesel, Agricultura Familiar e Produção de Alimentos”, realizada em Viçosa-MG, nos dias 26 e 27 de maio de 2011. Os slides foram disponibilizados pelo apresentador para utilização.
} 
perfil de agricultor familiar privilegiado pelo mercado no âmbito do PNPB é o da chamada agricultura familiar "consolidada" ou de "transição", mais apta a atender aos ditames de um processo de integração agroindustrial. $^{22}$

Todavia, levando em consideração a pequena porcentagem de investimento exigido nas aquisições de matérias-primas da agricultura familiar para aquisição do Selo Combustível Social; a concentração das usinas de biodiesel no Centro-Oeste (região onde predomina a agricultura patronal na produção de $\operatorname{soja}^{23}$ e a baixa participação da agricultura familiar na sojicultura ${ }^{24}$, pode-se afirmar que a soja utilizada para produção de biodiesel advém, sobretudo, do agribusiness, com destaque para empresas como a Cargill, a Louis Dreyfus Commodities, a ADM, a Bunge e a Caramuru Alimentos (Schlesinger 2008; Penido, 2011).

Nesses termos, tratar da produção nacional de biodiesel implica considerar como tem se dado a produção de soja no Brasil, cujas consequências - concentração de terras, conflitos fundiários, degradação da natureza, poluição decorrente do uso de agrotóxicos e desestruturação das relações de produção e de reprodução social no campo - passam a reverberar no interior da própria cadeia produtiva do biodiesel. As consequências da monocultura de soja, quando analisadas in loco, recaem sobre a reprodução social das populações camponesas, aumentando de forma significativa as desigualdades no campo e a concentração fundiária, já que a produção da soja se dá, preferencialmente, em grandes propriedades.

Nas novas áreas de expansão, rumo à Amazônia, a chegada da soja provoca uma valorização regional das terras, ocasionando conflitos entre os interessados em adquirir áreas para cultivar soja e posseiros, assentados e comunidades indígenas (Schlesinger \& Noronha, 2006). A utilização intensiva de agrotóxicos nas plantações de soja, principalmente de herbicidas, é outro problema e aparece como a principal denúncia da maioria dos entrevistados na pesquisa realizada por Schlesinger e Noronha (2006), explicitando os impactos sofridos pela população rural vizinha aos plantios de soja nos Estados do Mato Grosso, Pará e Tocantins.

O sebo bovino, por sua vez, considerado, como vimos, a segunda matéria-prima mais utilizada para produção de biodiesel, raramente aparece associado, no discurso governamental, ao biodiesel, sendo excluído das regras do Selo Combustivel Social, apesar de compor porcentagens crescentes do óleo utilizado como matéria-prima na maioria das usinas do Brasil. Questionando a "sustentabilidade" social e ambiental do biodiesel produzido a partir do sebo bovino, Repórter Brasil (2009) descortina a

\footnotetext{
${ }^{22}$ As ideias de agricultura familiar consolidada, de transição e periférica revelam a estratificação da agricultura familiar conforme nível de renda, critério que baliza o Pronaf e a compartimentação de seus grupos de "beneficiários". Penido (2011), ao analisar o PNPB, mostra sua relação com o Pronaf no trato da agricultura familiar como fornecedora de matérias-primas para produção de biodiesel.

${ }^{23}$ Quanto ao perfil das áreas produtoras de soja no Brasil, Schlesinger (2008) afirma a tendência à concentração da produção: “As propriedades com áreas de soja abaixo de 100 hectares diminuíram, entre 1985 e 1996, em 44,8\%. Por outro lado, as propriedades produtoras de soja com áreas acima de 1.000 hectares aumentaram em 11\%" (Schlesinger, 2008, p. 6). Ainda conforme o autor, no Centro-Oeste do país, as propriedades com área inferior a 100 hectares correspondiam, em 2006, a apenas $0,3 \%$ da produção de soja (Schlesinger, 2008, p. 5). “As propriedades com área entre 100 e 1.000 hectares respondiam por 22,7\% da produção e aquelas com área superior a 1.000 hectares pelos demais $77 \%$ " (dados para 2006. Schlesinger, 2008, p. 5).

${ }^{24}$ Conforme o Censo Agropecuário de 2006, a participação da agricultura familiar na produção de soja é de apenas de 16\%, concentrada, ainda, no sul do Brasil (IBGE, 2006).
} 
relação do biodiesel oriundo da gordura animal com a criação de gado em áreas desmatadas ilegalmente no Pará, no Mato Grosso e em outros estados da Amazônia Legal. Dados da Repórter Brasil (2009) evidenciam ainda que os municípios com maiores taxas de desmatamento são também os que possuem os maiores rebanhos e o maior número de casos fiscalizados de trabalho escravo. Ainda em 2014, dados da CPT indicam que a pecuária continua a figurar como o segmento agrícola com maior número de casos envolvendo trabalho escravo (49 casos e 318 escravos resgatados) em atividades de desmatamento para a preparação de novas áreas de pastagem (CPT, 2014).

Via de regra, o desmatamento para fins pecuários abre espaço para a monocultura da brachiaria (de origem africana), impactando a resiliência dos ecossistemas e homogeneizando as paisagens, na medida em que a gramínea se espalha com facilidade e impede o desenvolvimento de outros tipos de plantas. Nessa perspectiva, cabe destacar que o desmatamento responde por níveis elevados de geração de gases de efeito estufa, agravados, no caso da pecuária, pelas chamadas emissões entéricas (a digestão dos ruminantes responde por $22 \%$ da emissão mundial total de metano) (Repórter Brasil, 2009).

Embora, no início do PNPB, outras oleaginosas como a mamona e a palma tenham sido fortemente incentivadas (inclusive com isenções fiscais diferenciadas), para produção especialmente pela agricultura familiar do Semiárido Mineiro, do Norte e Nordeste do País ${ }^{25}$, as razões que condicionam a produção de biodiesel ao predomínio da soja e do sebo bovino são estritamente econômicas: logística favorável, disponibilidade de produção em larga escala e cadeia produtiva já estruturada. ${ }^{26}$ A dependência da soja para produção de biodiesel fortalece a lógica "mercadológica" do programa, em detrimento de seus pressupostos sociais. Assim, as empresas multiplicam seus ganhos ao atuarem de maneira integrada, financiando sojicultores, processando o grão e negociando o farelo, óleo e biodiesel.

Nesse cenário, o primeiro embate que se dá é entre os interesses do agribusiness dominante na cadeia produtiva da soja e os objetivos sociais do PNPB, que visam à integração da agricultura familiar (sobretudo daquela originária de regiões economicamente mais pobres) ao segmento industrial de biodiesel.

\footnotetext{
${ }^{25}$ Conforme Decreto n. ${ }^{\circ}$ 5.457, de 6 de junho 2005, os valores das isenções fiscais eram maiores para as usinas que adquiriam mamona ou palma da agricultura familiar das regiões Norte, Nordeste e Semiárido (Brasil, 2005b). Este decreto é alterado pelo Decreto n. ${ }^{\circ} 6.458$, de 14 de maio de 2008, que concede o benefício máximo na redução das alíquotas do PIS/PASEP e da COFINS para o biodiesel fabricado a partir de matérias-primas (sem especificação do tipo) produzidas nas regiões Norte, Nordeste e no Semiárido, adquiridas de agricultor familiar enquadrado no Pronaf (agricultores familiares que possuem a Declaração de Aptidão ao Pronaf-DAP) (Brasil, 2008). Em 2012, as regras de isenções tributárias do PNPB sofrem novamente alterações, com a revogação do Decreto n. $^{\circ} 6.458$ e o estabelecimento do Decreto n. ${ }^{\circ} 7.768$, de 27 de junho de 2012 , que outorga maiores porcentagens de isenção tributária para o biodiesel fabricado a partir de matérias-primas adquiridas de agricultor familiar enquadrado no Pronaf (sem especificação da região) e, secundariamente, para o biodiesel fabricado a partir da mamona ou da palma produzidas nas regiões Norte, Nordeste e no Semiárido, mas não necessariamente pela agricultura familiar (Brasil, 2012).

${ }^{26}$ Embora não seja o enfoque deste artigo analisar a inserção da agricultura familiar na cadeia produtiva do biodiesel, via PNPB, destacamos que tal processo de integração é permeado por contradições. De forma expedita, pode-se afirmar, a partir das análises de Penido (2011; 2015) para a agricultura familiar do Semiárido Mineiro e de Silva (2011) para os agricultores assentados na Fazenda Santa, em Canto do Buriti, Semiárido do Piauí, que as contradições do programa encontram-se na desconsideração das realidades locais e no seu caráter produtivista, regido por critérios econômicos/empresariais, incompatíveis, pois, com a racionalidade da agricultura familiar. Ademais, deve-se ressaltar que "a produção de oleaginosas para biodiesel desencadeia alterações nas relações espaciais locais, aumentando a dependência do agricultor em relação ao setor empresarial e aos rumos tomados pelo mercado nacional e global" (Penido, 2015, p. 213).
} 


\section{Considerações finais}

Todo um complexo de poder e alianças setoriais (Altieri \& Holt-Gimenez, 2007; Porto-Gonçalves, 2008) vem se articulando, em escala global, para a produção e o consumo de agrocombustíveis para servir ao fim único do consumo automotivo. As relações de poder em torno dos agrocombustíveis aprofundam os modelos do agribusiness e da agricultura industrial, contribuindo para a expropriação de grupos sociais subalternizados no rural brasileiro.

O impulso prioritário dos agrocombustíveis como substitutos paulatinos do petróleo na "matriz energética automobilística" acaba por servir a uma demanda insustentável em termos socioecológicos. A indústria automotiva, em torno da qual se estrutura um complexo conjunto de atividades centrais na economia de acumulação, implica, necessariamente, a produção de impactos ambientais extraordinários (Carneiro, 2005). Como analisado, com os agrocombustíveis não há, pois, alteração mínima que seja nas estruturas econômicas, sociais, políticas e culturais desenvolvidas sob o império dos combustíveis fósseis.

As soluções propostas, apenas do ponto de vista da substituição energética, sem tocar na necessidade de redução dos níveis de consumo, mantêm, pela via dos agrocombustíveis, o mesmo modelo de desenvolvimento intensivo em energia e na utiliza- ção de "recursos" naturais ${ }^{27}$. O problema, mais que o uso deste ou daquele combustível, encontra-se no alto consumo de energia demandado por uma frota rodoviária que não para de crescer. Logo, muito além do consumo imediato de energia, é sobre o ritmo e os modos de desenvolvimento da sociedade como um todo que incide, num horizonte de longo prazo, a problemática socioambiental.

Quanto ao discurso de promoção social do PNPB, observa-se que, embora a ênfase discursiva seja colocada na agricultura familiar, há uma hegemonia do agribusiness no setor, dado o predomínio da soja e do sebo bovino como matérias-primas para produção de biodiesel.

A regulação promovida pelo Estado para que o mercado insira a agricultura familiar na cadeia produtiva de biodiesel, por meio de incentivos econômicos e tributários, torna os mecanismos de controle estatais uma estratégia concebida apenas para auferir vantagens competitivas, em função dos benefícios econômicos e de marketing possibilitados pela concessão do Selo Combustivel Social.

As ações empreendidas, seja pelo mercado, seja pelo Estado, para conceder legitimidade aos agrocombustíveis e expandir sua produção contribuem para reforçar o ponto de vista segundo o qual os problemas socioambientais são passíveis de solução sem implicar alterações no atual modus operandi de produção e consumo.

\footnotetext{
${ }^{27}$ Cabe, aqui, problematizar a noção de "recurso", cuja utilização figura, comumente, naturalizada, consolidando uma visão instrumental da natureza. Tal visão não se dissocia da separação "Homem e Natureza", no cerne do pensamento e da sociedade moderna (Leach, 1985; Porto-Gonçalves, 2006). A necessidade de explorar a natureza responde à necessidade de criação de valor (de uso e de troca, em sua relação dialética), que expande a "forma-mercadoria" a todos os confins do planeta. Nesse processo, a natureza é reificada, vista tão somente como recurso a ser explorado, um mero fator de produção passível, pois, de valoração monetária.
} 


\section{Referências}

Acselrad, H. Políticas ambientais e construção democrática. In: Viana, G.; Silva, M.; Diniz, N. (Orgs.). O desafio da sustentabilidade: um debate socioambiental no Brasil. São Paulo: Fundação Perseu Abramo, 2001. p. 75-96.

Acselrad, H. As práticas espaciais e o campo dos conflitos ambientais. In: Acselrad, H. (Org.). Conflitos ambientais no Brasil. Rio de Janeiro: Relume-Dumará; Fundação Heinrich Böll, 2004. p. 13-35.

Acselrad, H. Apropriações sociais das mudanças climáticas. Democracia Viva, 43, 70-73, 2009. Disponível em: <https:// goo.gl/ptI5Er>.

Acselrad, H.; Pádua, J. A.; Herculano, S. Justiça ambiental e cidadania. Rio de Janeiro: Relume Dumará, 2004.

Altieri, M.; Holt-Gimenez, E. Benfeitores de biotecnologia e biocombustível: o poder de grandes finanças e as ideias. Correio da Cidadania, 2007. Disponível em: $<\mathrm{http}$ ://www. correiocidadania.com.br/antigo/ed540/pol2.htm>. Acesso em: jun. 2014.

Altvater, E. O preço da riqueza. São Paulo: Editora da UNESP, 1995.

ANP - Agência Nacional do Petróleo, Gás Natural e Biocombustíveis. Boletim Mensal do Biodiesel, julho de 2015. Disponível em: $<$ http://goo.gl/PBfnH1 $>$. Acesso em: ago. 2015.

Assis, W. F. T. Conflitos ambientais na produção de agrocombustíveis: colonialidade da natureza e manutenção da economia capitalista. In: Anais do IV Encontro Nacional da Associação Nacional de Pós-Graduação e Pesquisa em Ambiente e Sociedade (ENANPPAS). Brasília, 4, 5 e 6 de jun., 2008.

Assis, W. F. T.; Zucarelli, M. C. Despoluindo incertezas: impactos locais da expansão das monoculturas energéticas no Brasil. Belo Horizonte: O Lutador, 2007.

Aufheben. A importância dos carros para a economia moderna. In: Ludd, N. (Org.) Apocalipse motorizado: a tirania do automóvel em um planeta poluído. São Paulo: Conrad, 2004. p. 83-102.

Beck, U. La sociedad del riesgo: hacia una nueva modernidad. Barcelona: Paidós, 1998.
Beck, U. A política na sociedade de risco. Tradução de Estevão Bosco. Ideias, 1, nova série, 229-253, 2010. Disponível em: <http://goo.gl/dFPTGa>.

Bellacosa, J. M. Os desafios da reprodução camponesa frente à expansão dos agrocombustiveis: o assentamento Monte Alegre - Araraquara-SP. São Paulo, Dissertação (Mestrado em Geografia) - USP, 2012.

Bourdieu, P. O campo científico. In: Ortiz, R. (Org.). A sociologia de Pierre Bourdieu. São Paulo: Olhos d'Água, 2003. p. 112-143.

Brasil. Programa Nacional de Produção e Uso do Biodiesel. Biodiesel, o novo combustível do Brasil. Brasília: Ministério do Desenvolvimento Agrário, 2004. (Cartilha). Disponível em: <goo.gl/x7GBp7>. Acesso em: ago. 2014.

Brasil. Lei $n^{\circ} 11.097$ de 13 de janeiro de 2005. Dispõe sobre a introdução do biodiesel na matriz energética brasileira; altera as leis $\mathrm{n}^{\circ} 9.478$, de 6 de agosto de 1997, 9.847, de 26 de outubro de 1999 e 10.636, de 30 de dezembro de 2002; e dá outras providências. Brasília: DOU de 14/1/2005a.

Brasil. Decreto ${ }^{\circ}{ }^{\circ} 5.457$, de 6 de junho de 2005. Dá nova redação ao art. $3^{\circ}$ do Decreto n. ${ }^{\circ} 5.297$, de 6 de dezembro de 2004, que reduz as alíquotas da Contribuição para o PIS/ PASEP e da COFINS incidentes sobre a importação e a comercialização de biodiesel. Brasília: DOU de 7/6/2005b.

Brasil. Lei $n^{\circ} 11.326$, de 24 de julho de 2006. Estabelece as diretrizes para a formulação da Política Nacional da Agricultura Familiar e Empreendimentos Familiares Rurais. Brasília: DOU de 25/7/2006.

Brasil. Decreto $n^{\circ}$ 6.458, de 14 de maio de 2008. Altera o art. $4^{\circ}$ do Decreto n. ${ }^{\circ} 5.297$, de 6 de dezembro de 2004, que dispõe sobre os coeficientes de redução diferenciados das alíquotas da Contribuição para o PIS/PASEP e da COFINS incidentes na produção e na comercialização de biodiesel. Brasília: DOU de 15/5/2008.

Brasil. Instrução Normativa $n .{ }^{\circ} 1$, de 19 de fevereiro de 2009. Dispõe sobre os critérios e procedimentos relativos à concessão, manutenção e uso do Selo Combustível Social. Brasília: DOU de 25/2/2009.

Brasil. Decreto $n .^{\circ} 7.768$, de 27 de junho de 2012. Altera o Decreto n. ${ }^{\circ} 5.297$, de 6 de dezembro de 2004, que dispõe sobre os coeficientes de redução das alíquotas da Contribui- 
ção para o PIS/PASEP e da COFINS incidentes na produção e na comercialização de biodiesel, e sobre os termos e as condições para a utilização das alíquotas diferenciadas. Brasília: DOU de 28/6/2012.

Brasil. Portaria n. ${ }^{\circ} 81$, de 26 de novembro de 2014. Dispõe sobre os critérios e procedimentos relativos à concessão, manutenção e uso do Selo Combustível Social. Brasília: DOU de 27/11/2014.

Carneiro, E. Política ambiental e ideologia do desenvolvimento sustentável. In: Zhouri, A.; Laschefski, K.; Pereira, D. B. (Orgs.). A insustentável leveza da politica ambiental: desenvolvimento e conflitos socioambientais. Belo Horizonte: Autêntica, 2005. p. 27-47.

CMMAD - Comissão Mundial sobre o Meio Ambiente e o Desenvolvimento. Nosso Futuro Comum. Rio de Janeiro: Fundação Getúlio Vargas, 1991.

CONAB - Companhia Nacional de Abastecimento. Acompanhamento da safra brasileira: grãos, v. 2 - Safra 2014/15, n. 11. Décimo primeiro levantamento. Brasília: CONAB, ago. 2015a. Disponível em: <http://goo.gl/bUKqkG>. Acesso em: ago. 2015.

CONAB - Companhia Nacional de Abastecimento. Acompanhamento da safra brasileira: cana-de-açúcar, v. 2 - Safra 2015/16, n. 2. Segundo Levantamento. Brasília: CONAB, ago. 2015b. Disponível em: <http://goo.gl/fgbPB0>. Acesso em: ago. 2015.

Control, M. S. Acabem com todos os carros. In: Ludd, N. (Org.) Apocalipse motorizado: a tirania do automóvel em um planeta poluído. São Paulo: Conrad, 2004. p. 103-118.

CPT - Comissão Pastoral da Terra. Conflitos no campo Brasil 2014. Goiânia: CPT Nacional Brasil, 2014. Disponível em: <www.cptnacional.org.br>. Acesso em: mar. 2015.

EPE - Empresa de Pesquisa Energética. Análise de conjuntura dos biocombustiveis. Ano 2013. Brasília: Ministério de Minas e Energia, 2014. Disponível em: <http://goo.gl/ JSWh9s>. Acesso em: ago. 2015.

Faleiros, G. O Brasil do etanol e do biodiesel. Novo país ou grave crise? Rio de Janeiro: Loqüi Editora, 2008.

Firmino, R.; Fonseca, M. Uma discussão sobre os impactos ambientais causados pela expansão da agricultura: a produção de biocombustíveis no Brasil. In: Anais do IV Encontro Nacional da Associação Nacional de Pós-Graduação e Pesquisa em Ambiente e Sociedade (ENANPPAS). Brasília, 4, 5 e 6 de jun., 2008.
Folha Online. Leia as íntegras das declarações do presidente Lula e Bush, 10/03/2007. Disponível em: <http://goo.gl/ Iunfil>. Acesso em: maio 2015.

Foucault, M. A ordem do discurso. 16. ed. São Paulo: Edições Loyola, 2008.

Garcia, J.; Romeiro, A. Desafios para a produção de biodiesel por produtores familiares no semiárido brasileiro. Informações Econômicas, 40(1), 5-17, 2010. Disponível em: $<$ http://goo.gl/UZSs7T>.

Glass, V. Da ALCA ou álcool: eis a questão? Biocombustíveis: pauta de encontro de Lula e Bush, etanol é assunto delicado para o Brasil, 2004. Disponível em: $<$ http://goo. gl/iUeVzf $>$. Acesso em: set. 2014.

Glenister, D.; Nunes, V. Entendendo a produção sustentável de Biocombustíveis, a Diretiva da EU de energia renovável $e$ as iniciativas internacionais para verificação de sustentabilidade. SGS, junho de 2011. Disponível em: <http:// goo.gl/rlwt24>. Acesso em: fev. 2016.

Gorz, A. A ideologia social do automóvel. In: Ludd, N. (Org.). Apocalipse motorizado: a tirania do automóvel em um planeta poluído. São Paulo: Conrad, 2004. p. 73-82.

Harvey, D. O novo imperialismo. 2. ed. São Paulo: Edições Loyola, 2005.

Holleman, H.; Clausen, R. Os biocombustíveis, a BP-Berkeley e o Novo imperialismo ecológico. Resistir. info, 2008. Disponível em: <http://resistir.info/energia/ biofuels_jan08_p.html>. Acesso em: out. 2014.

IBGE - Instituto Brasileiro de Geografia e Estatística. Censo Agropecuário - Agricultura Familiar. Primeiros resultados, 2006. Rio de Janeiro: IBGE, 2006.

Illich, I. Energia e equidade. In: Ludd, N. (Org.). Apocalipse motorizado: a tirania do automóvel em um planeta poluído. São Paulo: Conrad, 2004. p. 33-71.

Lages, A. S., Penido, M. de O. Agrocombustíveis: Eldorado ou Carajás? In: Anais do XII Encontro de Geógrafos da América Latina (EGAL). Montevideo, 3 a 7 de abr., 2009.

Lander, E. (Org.). Colonialidade do saber: eurocentrismo e ciências sociais. Perspectivas latino-americanas. Buenos Aires: Clacso, 2005.

Laschefski, K. Agrocombustíveis: a caminho de um novo imperialismo ecológico? In: Zhouri, A.; Laschefski, K (Orgs.). Desenvolvimento e conflitos ambientais. Belo Horizonte: Editora UFMG, 2010. p. 63-91. 
Layrargues, P. P. A cortina de fumaça: o discurso empresarial verde e a ideologia da racionalidade econômica. São Paulo: Annablume, 1998.

Leach, E. Natureza/cultura. In: Gil, F. (Coord.). Enciclopédia Einaudi: Antropos-Homem. v. 5. Lisboa: Imprensa Nacional, 1985, p. 67-101.

Lefebvre, H. Espaço e política. Belo Horizonte: Editora UFMG, 2008.

Leroy, J. P. Prefácio. In: Bermann, C. (Org.). As novas energias no Brasil: dilemas da inclusão social e programas de Governo. Rio de Janeiro: FASE, 2007. p. 9-18.

Limoncic, F. A improvável modernidade fordista nas cidades brasileiras: um estudo das representações na Revista Quatro Rodas. Cadernos IPPUR, XIV(2), 93-119, 2000.

Ludd, N. Carros e remédio. In: Ludd, N. (Org.) Apocalipse Motorizado: a tirania do automóvel em um planeta poluído. São Paulo: Conrad, 2004. p. 15-32.

Maricato, E. O automóvel e a cidade. Ciência \& Ambiente, 37, 5-12, 2008. Disponível em: <https://goo.gl/GJji06>.

Martinez-Alier, J. Justiça Ambiental: local e global. In: Cavalcanti, C. (Org.). Meio ambiente, desenvolvimento sustentável e políticas públicas. 2. ed. São Paulo: Cortez; Recife: Fundação Joaquim Nabuco, 1999. p. 215-231.

Martins, S. M. Urbanização e automóveis: contradições espaciais do mundo moderno. In: Anais do XVI Congreso Latinoamericano de Transporte Público y Urbano. Cidade do México, 4 a 8 de out., 2010.

MME - Ministério de Minas e Energia. Brasil firma parceria com os EUA para desenvolvimento de biocombustível para aviação, 2011. Disponível em: <http://goo.gl/ ue2q5F>. Acesso em: jul. 2011.

Noble, D. F. O golpe climático corporativo. In: Almeida Júnior, A. R.; Andrade, T. N. de (Orgs.). Mídia e ambiente. São Paulo: Hucitec, 2009.

Orlandi, E. P. Análise de discurso: princípios \& procedimentos. Campinas: Pontes, 2001.

Paixão, M.; Fonseca, M. Exportações de etanol brasileiro, integração regional e a questão ambiental: uma análise empírica. In: Anais do IV Encontro Nacional da Associação Nacional de Pós-Graduação e Pesquisa em Ambiente e Sociedade (ENANPPAS). Brasília, 4, 5 e 6 de jun., 2008.
Penido, M. de O. O Programa Nacional de Produção e Uso de Biodiesel: alternativa ou "mais do mesmo"? Do domínio do agribusiness à inserção da agricultura familiar na cadeia produtiva do biodiesel no Norte de Minas. Niterói, Dissertação (Mestrado em Geografia) - UFF, 2011.

Penido, M. de O. O Programa Nacional de Produção e Uso de Biodiesel: a Petrobras e a agricultura familiar do Norte de Minas. Campo-Território: revista de geografia agrária, 10 (21), 192-220, 2015. Disponível em: <goo.g1/15xj4C>.

Porto-Gonçalves, C. W. Os (des) caminhos do meio ambiente. 14. ed. São Paulo: Contexto, 2006.

Porto-Gonçalves, C. W. Outra verdade inconveniente: a nova geografia política da energia numa perspectiva subalterna. In: Oliveira, M. P.; Coelho, M. C. N.; Corrêa, A. M. (Orgs.). O Brasil, a América Latina e o mundo: espacialidades contemporâneas. v. 1. Rio de Janeiro: Lamparina; Clacso; Anpege; Faperj, 2008. p. 328-365.

Repórter Brasil. O Brasil dos agrocombustiveis. Os impactos das lavouras sobre a terra, o meio e a sociedade. Gordura animal, algodão, dendê, pinhão-manso, girassol e canola, 2009. Disponível em: $<$ http://goo.gl/9GIV2E $>$. Acesso em: mar. 2010.

Schlesinger, S. Lenha nova para a velha fornalha: a febre dos agrocombustíveis. Rio de Janeiro: FASE, 2008.

Schlesinger, S.; Noronha, S. O Brasil está nu: o avanço da monocultura da soja, o grão que cresceu demais. Rio de Janeiro: FASE, 2006.

Silva, C. E. M.. Desenvolvimento e sustentabilidade nos cerrados: o caso do sertão norte-mineiro. In: Luz, C.; Dayrell, C. (Orgs.). Cerrado e desenvolvimento: tradição e atualidade. Montes Claros: CAA, 2000. p. 273-309.

Silva, M. E. S. da. Etnografia da terra prometida: trajetórias sociais, conflitos e cotidianos dos camponeses parceiros do assentamento da Fazenda Santa Clara: o caso da Brasil Ecodiesel no Piauí. Teresina, Dissertação (Mestrado em Antropologia e Arqueologia) - UFPI, 2011.

Weid, J. Marc von der. Agrocombustíveis: solução ou problema? In: Abramovay, R. (Org.). Biocombustiveis: a energia da controvérsia. São Paulo: Editora Senac, 2009. p. 99-142.

Zhouri, A.; Laschefski, K.; Pereira, D. B. Desenvolvimento, sustentabilidade e conflitos socioambientais. In: Zhouri, A.; Laschefski, K.; Pereira, D. B. (Orgs.). A insustentável leveza da política ambiental: desenvolvimento e conflitos socioambientais. Belo Horizonte: Autêntica, 2005. p. 11-24. 